\title{
Structural Models of Lithuanian Plosive Consonants in Different Word Positions
}

\author{
Sigita DEREŠKEVIČIŪTE் ${ }^{1}$, Asta KAZLAUSKIENE் \\ Department of Lithuanian Studies, Vytautas Magnus University, Lithuania
}

\begin{abstract}
This study examines the structural models of Lithuanian plosive consonants in intervocalic, word-initial and word-final positions. The research material consists of 24 sentences read three times by 6 native speakers. The results show that the plosive consonants can be composed of one to three phases, and the most frequent and common models are the closure with a burst release, which might be followed by a different degree of frication.
\end{abstract}

Keywords. Lithuanian, plosive consonant, structural model, voiced consonant, voiceless consonant

\section{Introduction}

It is well known that the traditional structure of plosive consonants consists of three stages in their production, involving a period of closure in the oral cavity (and of the velopharyngeal port), a burst or transient, which is generated by the sudden emission of intraoral pressure (upon constriction release), and aspiration phase in voiceless plosive consonants, which is created by noise turbulence at the glottis (and the fourth phase if uttered before a vowel - the transition into it) ([1], [2], [3], [4], [5] among others). From the acoustic point of view, a plosive consonant is a sequence of silence (a quiescent waveform) followed by a transient, i.e. a brief fricative-like noise segment and a random waveform, i.e. aspiration. However, "in between the transient and the aspiration, there is likely to be a brief interval of frication created in the mouth or at the lips as the lower articulator drags away from the upper" [6: 111]. Since both waveforms are random, normally these two phases are not distinguished from each other, rather "the term aspiration is used informally to cover the entire non-quiescent phase of a voiceless plosive" [6: 111]. Moreover, it is also known that the release stage might be modified so that no audible release occurs. This can happen "through overlap where the release occurs but is inaudible and through suppression of audible release" [7: 69]. Therefore, the aim of this study is to investigate the structure of these acoustic events and the possible modifications of the phases in greater detail. We expect that the results could be useful for developing a set of rules for automatic recognition systems. Additionally, the models are intended to be used for the future comparison of structural nature of consonants in different environments and their phonetic realizations in coarticulatory processes or consonantal clusters.

${ }^{1}$ Corresponding Author: Sigita Dereškevičiūtė; Vytautas Magnus University, V. Putvinskio st. 23-203, 44243 Kaunas, Lithuania; E-mail: sigita.dereskeviciute@vdu.lt. 
The acoustic features of Lithuanian consonants have already been analyzed ([8], [9], [10], [11], [12], [13]); however, the structural models demonstrating the acoustic sequences in detail have not received considerable scholars' attention and have not been described. Therefore, it is interesting to find out whether the models in the Lithuanian language follow the classical patterns, or some language-specific acoustic events may occur.

\section{Material and Method}

This paper presents the results of production experiment which examines the acoustic structural models of Lithuanian plosive consonants in intervocalic, word-initial and word-final positions. The segments with the consonants investigated were extracted using the automatic tools created at Vytautas Magnus University; the models were defined and classified manually based on the changes in sound waveform and spectrograms.

The research material consists of 24 sentences where the consonants under the present investigation [p], [b], [t], [d], [k] and [g] appeared mostly in [a] vowel context and different positions of a word: 6 sentences were composed of the target consonants in word- and phrase-initial position, 3 sentences in word- and phrase-final position and 12 sentences in intervocalic position. The sentences were read three times by 6 native speakers (3 men and 3 women aged 24-55; all of them have higher education and different public speaking skills). In total, 432 tokens were examined. The examples are

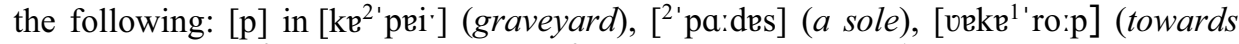
evening); [t] in [ ${ }^{2}$ ra:tes] (a wheel), [ ${ }^{2}$ ta:kes] (a path), [pe ${ }^{1}$ ga $\left.\mathrm{gt}\right]$ (to catch); [k]

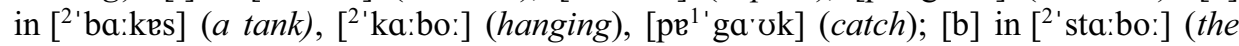
idol's), [2'ba:do:] (hunger's); [d] in [be ${ }^{2}$ da:vo:] (starved), [' ${ }^{2}$ da:ro:] (does, makes); [g] in [re' 'ga'vto:] (tasted), [''ga:vo:] (received).

The structural models and the duration of the consonants investigated were measured using the PRAAT software [14].

The models were defined with the labels $\mathrm{CL}$ - meaning a silent (or quasi-silent) closure, PW - a closure with a periodic (or quasi-periodic) waveform, PL - plosion (or transient) and FR - frication.

\section{Results and Discussion}

The experimental results have revealed 5 structural models, which could be generalized as $\mathrm{CL} / \mathrm{PW}+(\mathrm{PL})+(\mathrm{FR} / \mathrm{CL})$, where the first phase may be either a complete closure (CL) and, depending on the place of articulation of the voiceless consonants, may last 30-90 $\mathrm{ms}$ or a prevoicing interval $(\mathrm{PW})$ and, depending on the place of articulation of the voiced consonants, may be characterized by $25-80 \mathrm{~ms}$ duration. The second possible stage is a plosion interval (PL) which, depending on the place of articulation of the voiceless and voiced consonants, may last 5-30 ms. The velar consonants $[\mathrm{k}, \mathrm{g}]$ may consist of up to three bursts. Lastly, the first phase or the release stage may be 
accompanied by a frication period (FR $)^{2}$ of $10-20 \mathrm{~ms}$ or the second brief silent portion (CL, about 10-15 ms).

The labelling of the second/third segment as a silence closure (CL) may be a subject of discussion as, first, it may be articulatory impossible to create a complete closure after the burst release before the vowel; second, if there are perturbations in the waveform, the segment should be defined as FR. However, a decision was made to introduce the second closure portion in this experiment in order to highlight the difference between the segments with more attenuated and more intense amplitudes.

The plosive consonants are characterized by 5 models in the intervocalic position (see Table 1 and examples in Figures 1a-5a). The first phase CL is common to all voiceless consonants, while PW is common to voiced consonants. The models with plosion $(\mathrm{CL} / \mathrm{PW}+\mathrm{PL}+\mathrm{FR} / \mathrm{CL})$ are relatively common $(79 \%)$. The models with an unreleased burst are less frequent (a single closure phase or a closure occurring with frication, $21 \%$ ).

Table 1. The structural models of Lithuanian plosive consonants and their distribution $(\%)^{3}$

\begin{tabular}{llllllllllllllll}
\hline Structural model & \multicolumn{1}{l}{ VCV } & \multicolumn{1}{l}{ \#CV } & \multicolumn{4}{c}{ VC\# } \\
\cline { 2 - 15 } & $\mathbf{k}$ & $\mathbf{t}$ & $\mathbf{p}$ & $\mathbf{g}$ & $\mathbf{d}$ & $\mathbf{b}$ & $\mathbf{k}$ & $\mathbf{t}$ & $\mathbf{p}$ & $\mathbf{g}$ & $\mathbf{d}$ & $\mathbf{b}$ & $\mathbf{k}$ & $\mathbf{t}$ & $\mathbf{p}$ \\
\hline $\mathrm{CL} / \mathrm{PW}+\mathrm{PL}+\mathrm{FR}$ & 10 & 45 & 20 & 15 & 30 & & 30 & 50 & 10 & 15 & 20 & & 60 & 90 & 20 \\
$\mathrm{CL} / \mathrm{PW}+\mathrm{PL}$ & 25 & 30 & 50 & 55 & 50 & 60 & 10 & 30 & 50 & 80 & 80 & 80 & 20 & & 65 \\
$\mathrm{CL} / \mathrm{PW}+\mathrm{PL}+\mathrm{CL}$ & 50 & 15 & 15 & & 5 & & 60 & 20 & 40 & & & & & \\
$\mathrm{CL} / \mathrm{PW}+\mathrm{FR}$ & 5 & 10 & 5 & & 5 & & & & & 5 & & & 20 & 10 & 15 \\
$\mathrm{CL} / \mathrm{PW}$ & 10 & & 10 & 30 & 10 & 40 & & & & & & 20 & &
\end{tabular}

The structural model CL/PW+PL (see Figure $2 \mathrm{a}$ ) is predominant $(45 \%$ of the consonants in the intervocalic position). The ternary models CL/PW+PL+FR, $\mathrm{CL} / \mathrm{PW}+\mathrm{PL}+\mathrm{CL}$ and the monomial model $\mathrm{CL} / \mathrm{PW}$ are distributed very similarly $(20 \%$, $14 \%$ and $17 \%$, respectively). The models are illustrated in Figures $1 \mathrm{a}, 3 \mathrm{a}$, and 5 . The structural model CL/PW+FR is rare (4\%) in the intervocalic position (see Figure $4 \mathrm{a}$ ).

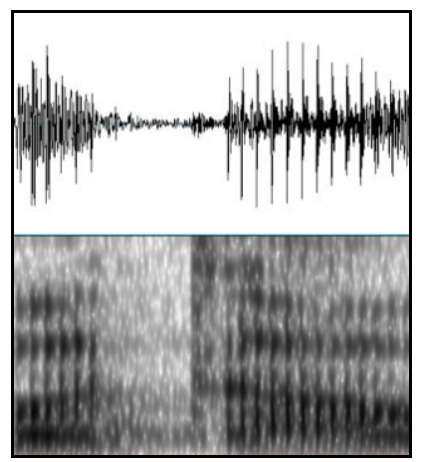

a) [d] in [' 'beda:vo:] (starved)

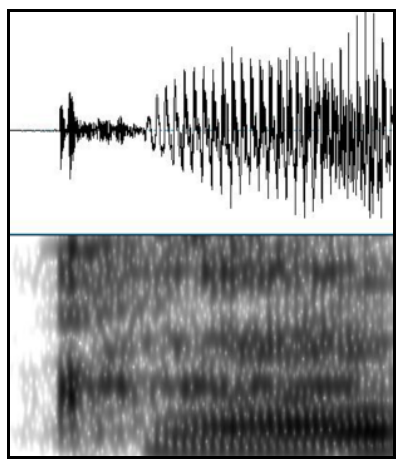

b) $[\mathrm{k}]$ in [ [' ka:bo:](hanging)

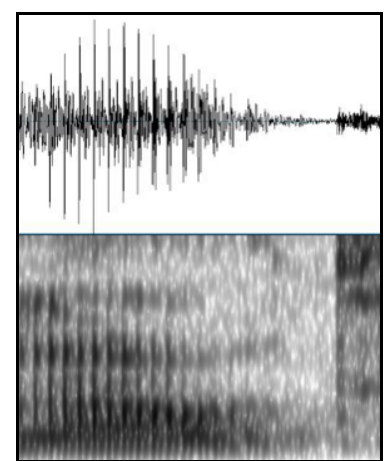

c) $[\mathrm{t}]$ in $\left[{ }^{1}\right.$ pega' $\left.\mathrm{tt}\right]$ (to catch)

Figure 1. The structural model CL/PW+PL+FR in: a) VCV, b) \#CV, c) VC\#

\footnotetext{
${ }^{2}$ In this study, the interval between the transient and a puff of air that follows it is referred to a different degree of frication and is not regarded as aspiration. The released breath is probably too short in duration to perceive it as aspiration. Nevertheless, no perception tests were conducted to validate the phenomenon. In the Lithuanian language, only voiceless consonants used in word-final position are considered to be aspirated, i.e. the accompanied frication noise is audible.

${ }^{3} \mathrm{C}$ marks consonant, V - vowel, \# - word-initial or word-final position.
} 
Almost all 5 models were found in the realization of voiceless consonants and voiced [d], whereas voiced [b] and [g] are less variable. Almost half of the examples of the voiced consonants are composed of two typical segments (PW+PL, $55 \%$ ), while voiceless consonants are characterized by a more complex structure: in the case of [t] and $[\mathrm{k}]$, before transition to the adjacent vowel, the PL phases may be accompanied by FR or CL (almost half of the examples of these consonants). An additional noise segment (FR) may appear in the production of the voiced consonants [d] (30\%) and [g] $(15 \%)$, but it never occurs in the production of the bilabial [b]. In the case of [p], CL+PL (50\%) is the most common model. The third part of voiced plosive consonants tend to be produced with an unreleased burst (PW, $26 \%$ ).

In the word-initial CV position, 5 models have also been identified; however, in this position, the production of consonants is more invariable. None of the consonants is defined by all models. In fact, there are three typical models for all voiceless consonants, whereas the voiced ones may be characterized by four different models but only one is predominant.

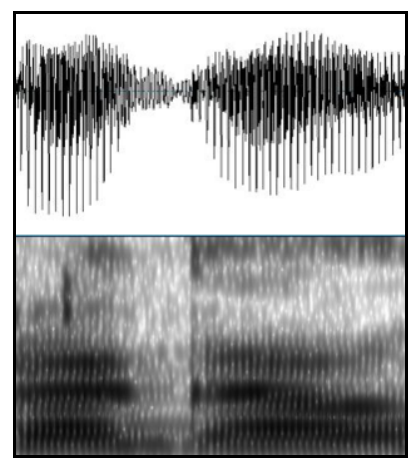

a) $[\mathrm{g}]$ in [ ' 'rrga'vto:] (tasted)

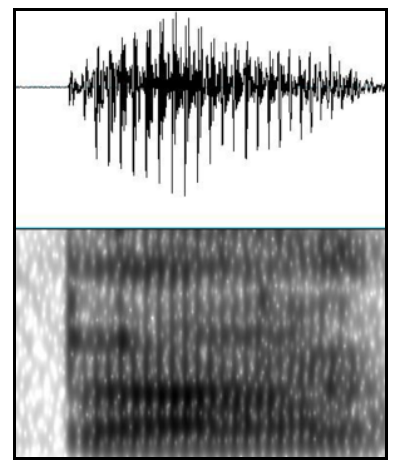

b) $[\mathrm{t}]$ in ${ }^{2}{ }^{1}$ ta:kes] (a path)

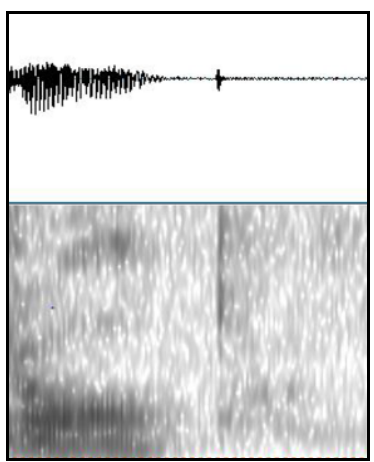

c) [p] in [veker $\left.{ }^{1} \mathrm{o}: \mathrm{p}\right]$ (towards evening)

Figure 2. The structural model $\mathrm{CL} / \mathrm{PW}+\mathrm{PL}$ in: a) $\mathrm{VCV}$, b) \#CV

The most frequent model as in VCV sequences consists of a closure and a burst release $(\mathrm{CL} / \mathrm{PW}+\mathrm{PL}, 55 \%$, see Figure $2 \mathrm{~b})$, and it is the most prevailing pattern among the voiced consonants $(80 \%$, see Table 1$)$. A different degree of accompanying noise may follow the release phase but it is less common (CL/PW+PL+FR, $21 \%$ and $\mathrm{CL} / \mathrm{PW}+\mathrm{PL}+\mathrm{CL}, 20 \%$, see Figures $1 \mathrm{~b}$ and $3 \mathrm{~b}$, respectively). The voiceless plosives tend to have these noise segments $(\mathrm{CL} / \mathrm{PW}+\mathrm{PL}+\mathrm{FR}, 30 \%$ and $\mathrm{CL} / \mathrm{PW}+\mathrm{PL}+\mathrm{CL}, 40 \%$, see Table 1).

Due to the laryngeal settings, the voiceless consonants do not exhibit any vibrational patterns and the silence phase of the closure merges with the prosodical pause in phrase- and word-initial positions. Therefore, it is impossible to determine the duration of the closure phase in this position. Nevertheless, the phase is not excluded in the production and, therefore, the label CL is assigned to the description of the models. The most frequent models are individual for each voiceless consonant: [k] $\mathrm{CL}+\mathrm{PL}+\mathrm{CL}(60 \%),[\mathrm{t}]-\mathrm{CL}+\mathrm{PL}+\mathrm{FR}(50 \%)$ and $[\mathrm{p}]-\mathrm{CL}+\mathrm{PL}(50 \%)$.

The voiced plosive consonants [b], [d] and [g] are defined by the binary model $\mathrm{PW}+\mathrm{PL}(80 \%)$ despite their place of articulation. The patterns where a burst release co-occurred with a CL segment were not observed. A closure accompanied by unreleased bursts is also uncommon for both voiceless and voiced consonants. It may 
happen only in the production of the bilabial consonant [b] (PW, $20 \%)$ and the velar [g] (PW+FR, $5 \%)$. However, in the latter case, it is likely to be an accidental or a speaker-specific case.

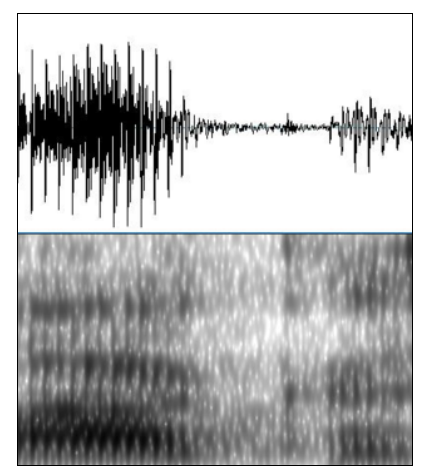

a) $[\mathrm{k}]$ in $\left[{ }^{2}\right.$ ba:kes] $($ a tank)

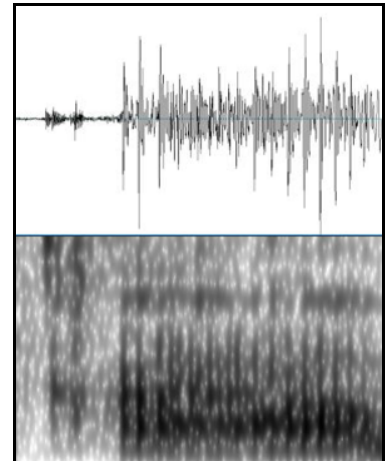

b) $[\mathrm{k}]$ in [ ' $\mathrm{ka}$ bo: (hanging)

Figure 3. The structural model $\mathrm{CL} /(\mathrm{PW})+\mathrm{PL}+\mathrm{CL}$ in: a) $\mathrm{VCV}, \mathrm{b}) \# \mathrm{CV}$

Only voiceless consonants can be used at the end of a word in Lithuanian. The results of the experiment have shown that 3 structural models with voiceless consonants occur in word- and phrase-final position: $\mathrm{CL}+(\mathrm{PL})+(\mathrm{FR})$. The burst is very often followed by frication (57\% see Figure 1c), especially for [t] $(90 \%)$ and less for [k] $-60 \%$. Bilabial [p] is characterized by the closure with a burst release and no obvious frication ( $65 \%$, see Figure $2 \mathrm{c}$ ). The consonants may also be produced without a strong audible plosion but rather with a hissing noise sound (CL+FR, $15 \%$, see Figure 4b). In word- and phrase-final position, when the articulators are getting ready to relax, the muscular tension decreases, the glottis maintains open longer, unreleased bursts could be expected. Nevertheless, the results show that the transient segment is typically present $(\mathrm{CL}+\mathrm{PL}+(\mathrm{FR}))$, which means that consonants are rather produced with stronger buildups of pressure and/or tenser articulation.

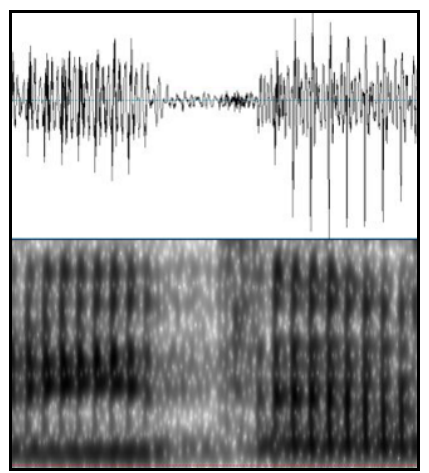

a) $[\mathrm{d}]$ in [t'jkreI ${ }^{2}$ 'da:ro: (really

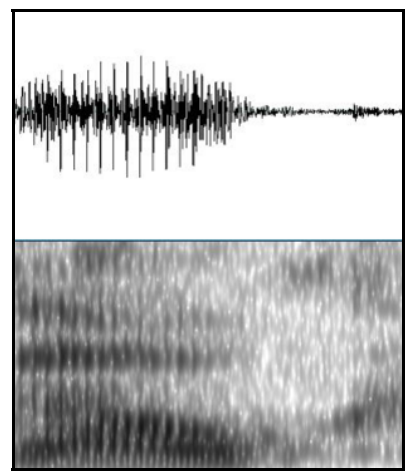

b) $[\mathrm{k}]$ in [ ${ }^{1}$ pega' vk] (catch)

Figure 4. The structural model CL/PW+FR in: a) VCV, b) VC\# 


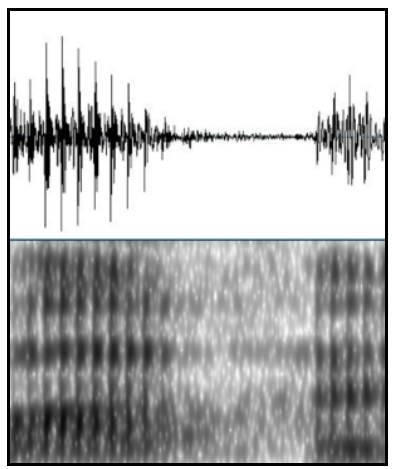

$[\mathrm{k}]$ in ${ }^{2}{ }^{\prime}$ ba:kes] $($ a tank $)$

Figure 5. The structural model CL/PW in VCV position

Considering all models regardless the position of the consonant in the word or the absence or presence of voicing, the most frequent model of plosive consonants is the binomial pattern, i.e. a closure released with a burst (46\%), confirming this structural model to be the most classical one. One third of the data has demonstrated that plosives are produced with frication $(28 \%)$. From the articulatory point of view, this means that the voicing of the following vowel (in VCV, CV sequences) starts simultaneously upon the oral release or shortly thereafter. The rarest pattern is when the closure is released not with a brief plosion but with a continuous frication interval (CL/PW+FR, $5 \%$ ). It is also possible but untypical to generate plosive consonants only by their closure (CL/PW, 8 \%).

Regarding voicing despite the position of consonants in a word, the most frequent pattern is $\mathrm{CL}+\mathrm{PL}+\mathrm{FR}$ for voiceless consonants $(37 \%)$ and $\mathrm{PW}+\mathrm{PL}$ for voiced consonants $(68 \%)$. As a rule, the voiceless plosive consonants are pronounced with more muscular energy and they tend to have longer and stronger pressure increases than their voiced counterparts [15], [16]. Moreover, after the voiceless plosive consonants before voiced sounds, it takes longer for the vocal folds to start vibrating [17]. Therefore, it is more frequent that during the lag between the release of obstruction and the onset of voicing, turbulent air comes through the open glottis. All these obstruent consonants probably may display stronger or weaker friction because of the articulatory gestures. Within the period of time when the articulators are getting apart and shifting to a different configuration in the vocal tract, a weaker or stronger puff of air may come along, especially in the case of voiceless consonants when the glottis is still open. Therefore, the voiceless consonants tend to be pronounced with a shorter or longer frication noise (FR) in all positions.

In contrast to voiceless consonants, the voiced plosives are relatively weaker with regard to energy, and the release of additional breath is hardly noticeable. Additionally, the energy is partly used up for the vibrational processes of the vocal folds; therefore, the pronunciation of the voiced plosives might be weaker and sometimes unreleased.

The distribution of the frequency of the structural models is irregular also in regard to the place of articulation of the plosive consonants. The dental consonants [t] and [d] tend to be the most frequently fricated (CL/PW+PL+FR) among other consonants in all positions: in the initial position [t] $-45 \%$, [d] $-30 \%$, in the medial position $[\mathrm{t}]-50$ $\%$, [d] $-20 \%$, in final $-[\mathrm{t}]-90 \%$. The burst accompanying the segment is also common to the velar plosive [k], but here, the plosion is followed by strongly 
attenuated frication acoustically similar to the phase of a complete closure $(\mathrm{CL}+\mathrm{PL}+\mathrm{CL}$, in VCV sequences $-50 \%$, in $\mathrm{CV}-60 \%)$. The generation of a turbulent noise of a different degree may be caused by possible differences in the changes of intraoral pressure (correlated with the size of the cavity behind the supraglottal constriction) or in the speed of movements of different articulators in the production of dentals and velars. The bilabials [p] and [b], which are articulated in the most front position, are usually pronounced without a frication noise or it is very weak (PW+PL). The voiced bilabial [b], in turn, may also have no plosion (PW) at all. As Miller and Daniloff observed, the "low subglottal pressures, combined with short closure durations, might not permit the buildup of intraoral pressures sufficient for burst transients to occur at consonantal release" [18: 351]. It is also possible that the burst is released, but it overlaps with the following vowel.

\section{Conclusions}

In conclusion, the plosive consonants can be composed of one to three phases, or from two to three phases in the case of voiceless consonants in word final position. The most typical model consists of two phases: a closure and a burst release, which is immediately followed by the vibratory patterns of the next vowel. However, consonants require pressure buildups behind the oral closure until a rapid opening of constriction, which consequently causes the creation of a sudden brief flow of air of a different degree (FR or CL). In most cases, this reflects the production of voiceless consonants, especially articulated in the front part of the oral cavity.

The metaphorical denotation of these consonants does not always reflect their phonetic realization, and the plosive consonants are not required to have a constant number of phases as it is usually expected in Lithuanian linguistics. The next stage of this study is to investigate the structural models of plosive consonants in consonant clusters.

\section{Acknowledgment}

The research was carried out within the framework of the EU Structural Funds project "The Development of the Public Electronic Services of the Lithuanian Language Syntactic and Semantic Analysis Information System (SEMANTIKA 2)" no. 02.3.1CPVA-V-527-01-0002, financed/funded by the European Regional Development Fund. For the help in extracting the data, we express our sincere thanks to our colleague Assoc. Prof. Gailius Raškinis from the Department of Systems' Analysis, Vytautas Magnus University.

\section{References}

[1] Fant G. The Acoustic Theory of Speech Production. The Hague, Netherlands: Mouton; 1960. 323 p.

[2] Lass, NJ, editor. Speech and Language. Advances in Basic Research and Practice. 1st ed. vol. 11. London: Academic Press, 1984. 396 p.

[3] Lieberman P, Blumstein SE. Speech physiology, speech perception, and acoustic phonetics. Cambridge: Cambridge University Press. 1988. 249 p. 
[4] Johnson K. Acoustic and auditory phonetics. 2nd ed. Hoboken, New Jersey: Wiley-Blackwell; 2003. $192 \mathrm{p}$.

[5] Stevens KN. Acoustic phonetics. Cambridge, MA: MIT Press. 1988. 624 p.

[6] Hewlett N, Beck J. An Introduction to the Science of Phonetics. New York: Routledge, 2006. 368 p.

[7] Ball MJ, Rahilly J. Phonetics. The Science of Speech. London: Arnold. 1999. 239 p.

[8] Kliukienė R. Šiaurès žemaičių tarmès konsonantizmas: akustinès ir audicinès ypatybės. Vilnius: Vilniaus universitetas. 2011. 168 p.

[9] Dereškevičiūtė S. Lietuvių kalbos priebalsių akustinès ypatybės. Doctoral Dissertation. Kaunas. 2013.

[10] Ambrazevičius R, Leskauskaitė A. Priebalsių akustinès ypatybės: palatalizacija ir balsingumas. Kaunas: Technologija. 2014. 312 p.

[11] Urbanavičienė J, Indričāne I. Lietuvių ir latvių kalbų trankieji priebalsiai: lokuso lygčių rezultatai. Baltistica. 2015; 50 (2): 261-293.

[12] Urbanavičienė J, Indričāne I. Lietuvių ir latvių kalbų uždarumos priebalsiai: sprogimo fazès trukmė ir FFT spektrai. Žmogus ir žodis. Didaktinė lingvistika, 2016; 18(1): 46-79.

[13] Jaroslavienė J, Grigorjevs J, Urbanavičienė J, Indričāne I. Baltų kalbų garsynas XXI a. pradžioje: Balsių ir garsų sąveikos instrumentinis tyrimas. Collective monograph. Vilnius: Lietuvių kalbos institutas. 2019. 317 p.

[14] Boersma P, Weenink D. 2018. Praat: doing phonetics by computer, version 6.035. www.praat.org.

[15] Sharf DJ. Duration of Post-Stress Intervocalic Stops and Preceding Vowels. Language and Speech, 1962; 5(1), 26-30.

[16] Arkebauer H, Hixon T, Hardy J. Peak Intraoral Pressures During Speech. Journal of Speech and Hearing Research. 1967; 10(2): 196-208.

[17] Speck BP, Valor MLG. A Practical Introduction to English Phonology. 2nd ed. Valencia: Universitat de Valencia, 2015. $120 \mathrm{p}$.

[18] Miller CJ, Daniloff R. Aerodynamics of Stops in Continuous Speech. Journal of Phonetics 1977; 5(4): $351-360$. 